\title{
Effects of Genetic and Agronomic Factors on Grain Composition in Oats
}

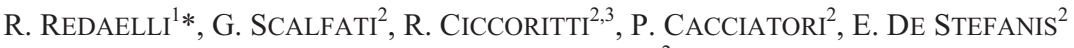 \\ and D. SGRULletTA ${ }^{2}$ \\ ${ }^{1}$ Consiglio per la ricerca e la sperimentazione in agricoltura, Research Unit for Maize Culture, \\ Via Stezzano 24, 24126 Bergamo, Italy \\ ${ }^{2}$ Consiglio per la ricerca e la sperimentazione in agricoltura, Research Unit for Cereal Quality, \\ Via Cassia 176, 00191 Roma, Italy \\ ${ }^{3}$ Campus Bio-Medico Rome-University, Via Alvaro del Portillo 21, 00128 Roma, Italy
}

(Received 9 January 2014; Accepted 28 March 2014;

Communicated by J. Johnson)

\begin{abstract}
The effects of genetic variability and agronomic practises on the chemical compounds of the grain were evaluated in a set of oat cultivars (16 naked and four husked) grown in different experiments in the years 2004-2008. In the first experiment, carried out for two years, $\beta$-glucan and Total Dietary Fibre (TDF) from eight oat cultivars, grown under three different levels of nitrogen fertilization and two seed doses, were considered. The second experiment, involving 12 cultivars for two years, explored the variation of $\beta$-glucan solubility and further characterized six cultivars for the content of TDF and arabinoxylans. In both experiments, genotype was found to exert the largest effect on the grain composition; nitrogen levels and seed doses had positive significant effects on protein and $\beta$-glucan contents, but did not affect fibre content. Among the naked cultivars, Irina, Abel, Luna, Hendon and Expression showed a good ability to accumulate the examined grain compounds. However, in general, the highest contents of protein and $\beta$-glucan were found in the groats of husked cultivars, suggesting that specific breeding programs are a crucial step to identify the suitable naked oat genotypes to produce foods of high nutritional value.
\end{abstract}

Keywords: naked oats, $\beta$-glucan, TDF, agronomic factors, nutritional quality

\section{Introduction}

Whole grain cereals may have an important role in the prevention of chronic diseases, by reducing the risk for cardiovascular disease, cancer, diabetes and obesity (Slavin et al. 1999). They are in fact a rich source of unique bioactive components that can provide health benefits (Liu 2007). Among cereals, whole grain oats (Avena sativa L.) contain a high amount of dietary fibre and soluble fibre, which can help improve carbohydrate metabolism and reduce serum lipid (Brennan and Cleary 2005; Shewry et al. 2008). They also represent a source of good quality storage proteins and other compounds with func-

* Corresponding author; E-mail: rita.redaelli@entecra.it; Phone: +39 035 313132; Fax: +39 035316054 
tional properties, like unsaturated lipids, antioxidants and vitamins (Peterson 1992). The interest in oats for food industries is increasing with the numerous evidences of its beneficial effects on health (Davy et al. 2002; Jenkins et al. 2002), mainly associated with the protein and $\beta$-glucan functionality and their potential use in the diet of people with celiac disease (Arentz-Hansen et al. 2004; Haboubi et al. 2006). As a part of a large project aimed at opening new commercial opportunities for oats grain, the possible use of naked oats as raw materials was studied (Sgrulletta et al. 2005; Redaelli et al. 2006). The good nutritional quality of naked oats, as derived from previous data, strongly recommended their utilization for on farm cultivation and the food industry, also considering that technological processes could result more convenient, as the cost of the de-hulling step can be avoided (Peltonen-Sainio et al. 2004). Moreover, due to their lower surface roughness, the final naked oat-based products could be more easily accepted by the consumers. Attention was also paid to breeding programs for developing new naked oat varieties of high quality from the technological and nutritional point of view (Redaelli et al. 2007; Sgrulletta et al. 2008). Unfortunately, the available information on the agronomic factors that affect yield and nutritional quality of naked oats is scarce. By contrast the influence of both genetic and environmental factors on $\beta$-glucan, protein and oil content in husked oats has been evidenced by several studies. A wide genetic diversity in $\beta$-glucan concentrations was found to be associated with high heritability and significant genotype $\times$ environment interaction (Lim et al. 1992). Weightman et al. (2004) evidenced that increasing ammonium nitrate rates exert a positive effect on protein content but not on $\beta$-glucan concentration of winter oats. Saastamoinen et al. (2004) reported no significant effects of traditional vs. organic cultivation on $\beta$-glucan accumulation. Genetic origin and, to a minor extent, soil fertility, were found to have a large impact on oat grain components (Brennan and Cleary 2005; Peterson et al. 2005). In their work Tiwari and Cummins (2009a) pointed out that genotype, environment, agronomic practices and their interactions can have a positive or negative impact on cereal $\beta$-glucan levels. Moreover, the same authors (Tiwari and Cummins 2009 b) developed a mathematical model able to assess the relative importance of various factors (genetic, agronomic and environmental) on $\beta$-glucan levels during the cultivation of oats. Finally, the impact of genetic and environmental factors on $\beta$-glucan content was described in a large European germplasm collection, including many accessions different from A. sativa L. (Redaelli et al. 2013).

As for naked oats, the agronomic factors that affect their yield and nutritional quality was described by Givens et al. (2000). The role of crop rotation and environment on grain bioactive components in a group of naked oats was also examined (Redaelli et al. 2009). Finally, the effect of fertilization on the content of $\beta$-glucan in naked oats was explored (Havrlentová et al. 2013).

As a part of a large project aimed at opening new commercial opportunities for naked oats, the intrinsic and extrinsic factors which could affect their nutritional value, like genotype, climatic conditions, nitrogen fertilizer application and seed dose, have been considered. Using the data from different experiments carried out during four years with sixteen naked and four husked cultivars, the relative importance of climate and agronomic practises on protein and fibre component contents of oat whole grain was evaluated. 


\section{Materials and Methods}

\section{Plant material, location and design}

The oat genotypes used in this study are listed in Table 1. As a first step to identify cultivars and lines with a higher yield and a good nutritional quality, we explored the agronomic and biochemical characteristics of the available naked oats. Italian germplasm was represented by Nave, released in 1983, the only cultivar present on the market in 2004, and two breeding lines, obtained from our programs, which were later registered as Irina and Luna. This group was implemented by different cultivars from other countries, in which breeding programs for naked oats had a larger diffusion than in Italy. Two-field trials (experiments I and II) were carried out at Montelibretti (Rome, Italy, $65 \mathrm{~m}$ above sea level).

Table 1. List of the oat genotypes used in this study

\begin{tabular}{|c|c|c|c|c|c|}
\hline Genotype & Origin & $\begin{array}{l}\text { Year of } \\
\text { release }\end{array}$ & Genotype & Origin & $\begin{array}{l}\text { Year of } \\
\text { release }\end{array}$ \\
\hline Abel & Czech Republic & 1995 & Hja72095N & Finland & - \\
\hline BD123 & Italy & - & Irina & Italy & 2009 \\
\hline BD124 & Italy & - & Konradin & Germany & - \\
\hline Bionda $^{a}$ & Italy & 2003 & Kynon & United Kingdom & - \\
\hline Donata $^{a}$ & Italy & 1999 & Luna & Italy & 2009 \\
\hline Expression & United Kingdom & 2002 & Nave & Italy & 1983 \\
\hline Flavia $^{a}$ & Italy & 1996 & Racoon & United Kingdom & 2005 \\
\hline Grafton & United Kingdom & 1998 & Rhea $\times$ Padarn & France & - \\
\hline Hamel $^{\mathrm{a}}$ & France & 2000 & Zuton & United Kingdom & 2006 \\
\hline Hendon & United Kingdom & 2001 & & & \\
\hline
\end{tabular}

${ }^{a}$ Husked cultivars.

Experiment I. Six naked oat cultivars and breeding lines: Abel, Hja72095N, Irina, Konradin, Kynon, Rhea $\times$ Padarn 542 and two husked cultivars: Donata and Flavia, were grown on sandy soil in two successive agronomic seasons (2004-05 and 2005-06) at two seed doses, 300 and 400 viable seeds $\mathrm{m}^{-2}$. Organic nitrogen (Bio-land 3\%) was applied at three different levels $\left(0,40\right.$ and $\left.80 \mathrm{~kg} \mathrm{ha}^{-1}\right)$.

Experiment II. Ten naked oat cultivars and breeding lines: BD123, BD124, Expression, Grafton, Hendon, Irina, Luna, Nave, Racoon and Zuton and two husked cultivars (Bionda and Hamel) were grown in 2006-07 and 2007-08 at the seed dose of 400 viable seeds $\mathrm{m}^{-2}$. Fertilization consisted in the application of $40 \mathrm{~kg} \mathrm{ha}^{-1}$ organic nitrogen (Bio-land $3 \%$ ).

In both experiments, cultivars were grown in $10 \mathrm{~m}^{2}$ plots in a randomized block design with three replications, and fava bean (Vicia faba L.) as the preceding crop.

\section{Yield and physical grain traits}

After harvest, yield ( $\mathrm{t} \mathrm{ha}^{-1}$ at $13 \%$ moisture) was recorded from each plot. Seed weight (g, calculated on 1000 seeds previously cleaned) and hectoliter weight $\left(\mathrm{kg} \mathrm{hL}^{-1}\right.$, measured by a Shopper chondrometer equipped with a $250 \mathrm{ml}$ cylinder) were also evaluated in a repre- 
sentative sub-sample of each plot, which was sent to the laboratory for the successive chemical analyses. The samples were kept at $4{ }^{\circ} \mathrm{C}$ until analysis.

\section{Chemical analyses}

All reagents were of analytical spectrophotometric grade (Carlo Erba, Rome, Italy). The husked oats were de-hulled by hand before analysis. Milling was carried out by a Udy Cyclotec mill with a $0.5 \mathrm{~mm}$ sieve. Moisture was determined with a thermo-balance (Sartorius MA 40 - Gottingen, Germany) at $120^{\circ} \mathrm{C}$. Grain samples were analyzed for protein content (micro-Kjeldhal nitrogen analysis, $\mathrm{N} \times 6.25$ ). The enzymatic method of McCleary and Codd (1991) was utilized for total $\beta$-glucan determination using a Megazyme $\beta$-glucan kit (mixed linkage $\beta$-glucan, K-BGLU 07-11) purchased from Megazyme International Ireland. The insoluble fraction of $\beta$-glucan was separated and analyzed after incubation for 120 min with distilled water at $38^{\circ}$ following the method of Åman and Graham (1987); soluble $\beta$-glucan content was obtained by subtracting insoluble from total $\beta$-glucan content as also reported by Lee et al. (1997). Total dietary fibre (TDF) was determined with the AOAC method (1995); total arabinoxylan content was evaluated according to Englyst et al. (1994) on total fibre residues (Ciccoritti et al. 2011). All analyses were carried out in duplicate.

\section{Statistical analyses}

Analysis of variance (ANOVA) was carried out separately for each experiment with a split-plot model, with year as the main factor and nitrogen, seed dose and/or cultivar nested on it (MSTATC, Michigan State University, East Lansing, MI). In the statistical analysis year $(\mathrm{Y}), \mathrm{N}$ treatment $(\mathrm{N})$, seed dose $(\mathrm{S})$ and cultivars $(\mathrm{C})$ were considered as fixed effects. Simple correlation coefficients (r) among agronomic, physical and chemical traits were also calculated.

Multivariate analysis, performed with MATLAB software (R2010a version, MathWorks Inc., USA), was applied to study the variations associated with the environment for the variables under study. In the comparisons among environments box-plots were used and descriptive statistics, the median, the upper and lower quartiles and the minimum and maximum data values were displayed.

\section{Results}

\section{Climatic characteristics}

The climatic characteristics of the two experiments are illustrated in Fig. 1. In the first experiment, the mean values of minimum and maximum temperature of the two growing seasons were similar $\left(9.3-17.7^{\circ} \mathrm{C}\right.$ in $2004-05$ and $8.7-17.3^{\circ} \mathrm{C}$ in $\left.2005-06\right)$. In the first months of 2006 a reduced availability of water was recorded, with a strong decrease of rainfall in May and June and a significant difference in the total rainfall $(-11 \%)$ as compared to the first year (416 vs. $469 \mathrm{~mm})$. 


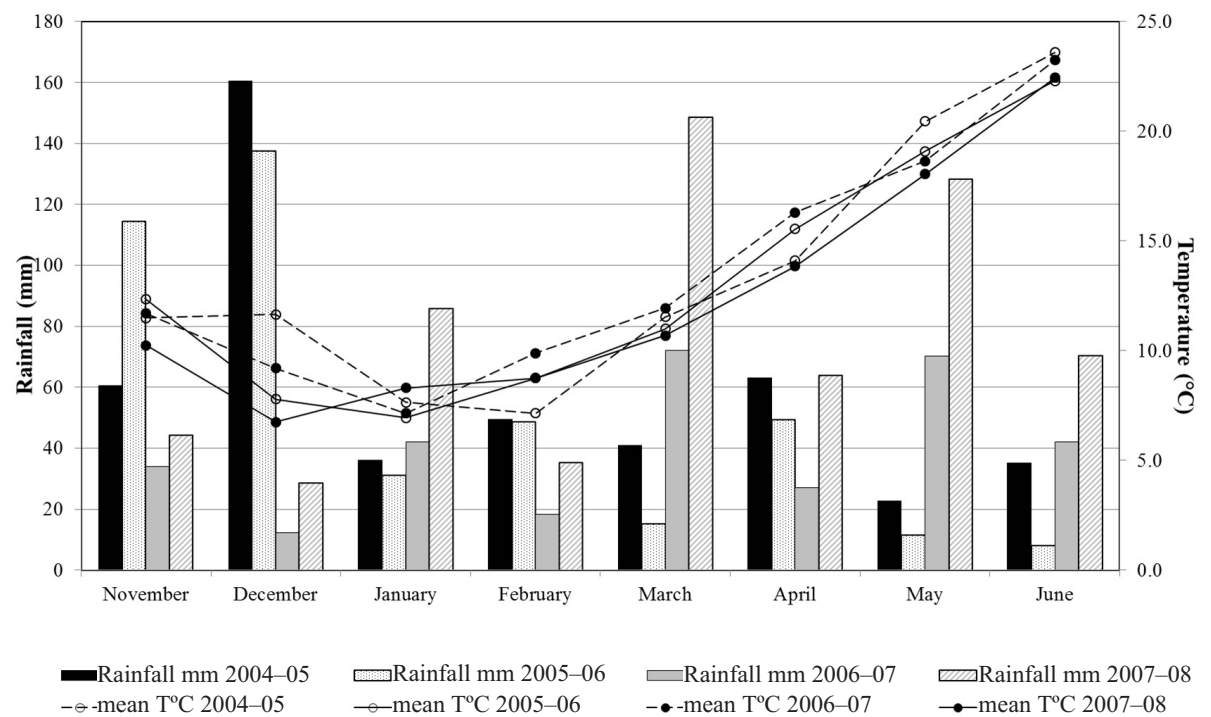

Figure 1. Rainfall $(\mathrm{mm})$ and mean temperatures $\left({ }^{\circ} \mathrm{C}\right)$ in the two experiments

In the second experiment, 2006-07 season was characterized by higher temperatures (the mean temperature was $13.5{ }^{\circ} \mathrm{C}$, as compared to $12.4{ }^{\circ} \mathrm{C}$ in the second year). In 2006-07 the unusually mild winter determined a rapid growth of the plants, a vast diffusion of powdery mildew and, as a consequence, a reduced yield. Rainfall was more abundant in 2007-08 (605 mm vs. 318 in 2006-07), and affected the plants with extended lodging.

\section{Statistical analysis}

The impact of the climatic factors on the agronomical and physical parameters of the cultivars is summarized in Table 2, where the mean values for each agronomic season are reported. The data from the first experiment indicated a higher yield performance and a better technological quality, in terms of seed weight and hectolitre weight, as compared to the second experiment.

The mean values of the traits from the first experiment were compared by Duncan's test and indicated a different response of naked and husked genotypes to the applied agro-

Table 2. Mean seasonal values $( \pm \mathrm{SD}$ ) for some agronomic and physical traits in experiments I and II

\begin{tabular}{lcccccc}
\hline & \multicolumn{2}{c}{$\mathrm{I}$} & & \multicolumn{2}{c}{ II } \\
\cline { 2 - 3 } \cline { 5 - 6 } & $2004-05$ & $2005-06$ & & $2006-07$ & $2007-08$ \\
\hline Yield (t ha $\left.{ }^{-1}\right)$ & $4.36 \pm 1.05$ & $4.07 \pm 1.08$ & & $1.27 \pm 1.07$ & $2.17 \pm 0.57$ \\
Seed weight (mg) & $22.1 \pm 6.41$ & $24.4 \pm 5.30$ & & $19.8 \pm 3.53$ & $15.7 \pm 1.38$ \\
Hectoliter weight $\left(\mathrm{kg} \mathrm{hL}^{-1}\right)$ & $56.3 \pm 4.44$ & $59.8 \pm 5.01$ & & $54.0 \pm 6.14$ & $45.7 \pm 2.12$ \\
\hline
\end{tabular}


nomic practices. In fact, naked cultivars showed a positive and significant variation of yield in response to a higher nitrogen level, whereas husked cultivars appeared to be less influenced by this factor; on average, changes from $3.39 \pm 0.76$ (N0) to $4.02 \pm 0.48 \mathrm{tha}^{-1}$ (N80) and from $5.54 \pm 0.98$ (N0) to $5.66 \pm 0.58$ (N80) $\mathrm{t} \mathrm{ha}^{-1}$, were observed in naked and husked oat varieties, respectively. On the other hand, nitrogen treatment determined small variations of hectolitre weight in both husked and naked oats (data not shown).

Table 3. Mean Square values for protein, $\beta$-glucan and TDF in the first experiment (2004-2006)

\begin{tabular}{lcccc}
\hline \multicolumn{5}{c}{ Mean square } \\
\hline Source of variation & DF & Protein & Total $\beta$-glucan & TDF \\
\hline Year (Y) & 1 & $172.52^{* *}$ & $18.98^{* *}$ & $\mathrm{~ns}$ \\
Nitrogen (N) & 2 & $10.97^{* *}$ & $2.22^{* *}$ & $\mathrm{~ns}$ \\
$\mathrm{Y} \times \mathrm{N}$ & 2 & $4.30^{* *}$ & $0.31^{* *}$ & $\mathrm{~ns}$ \\
Seed dose (S) & 1 & $8.86^{* *}$ & $0.91^{* *}$ & $\mathrm{~ns}$ \\
$\mathrm{Y} \times \mathrm{S}$ & 1 & $12.38^{* *}$ & $1.16^{* *}$ & $\mathrm{~ns}$ \\
$\mathrm{~N} \times \mathrm{S}$ & 2 & $1.55^{*}$ & $0.07^{*}$ & $\mathrm{~ns}$ \\
Cultivar (C) & 7 & $97.96^{* *}$ & $9.76^{* *}$ & $66.75^{* *}$ \\
$\mathrm{Y} \times \mathrm{C}$ & 7 & $3.36^{* *}$ & $0.81^{* *}$ & $10.65^{* *}$ \\
$\mathrm{~N} \times \mathrm{C}$ & 14 & $\mathrm{~ns}$ & $0.20^{* *}$ & $\mathrm{~ns}$ \\
$\mathrm{~S} \times \mathrm{C}$ & 7 & $1.27^{* *}$ & $0.19^{* *}$ & $1.30^{* *}$ \\
Error & 180 & 0.36 & 0.02 & 0.40 \\
\hline
\end{tabular}

$\mathrm{DF}=$ degrees of freedom; $\mathrm{ns}=$ not significant; $* p \leq 0.05 ; * * p \leq 0.01$

The ANOVA with the combined effects of year, nitrogen level and seed dose on the accumulation of protein, total $\beta$-glucan and TDF in the first experiment is reported in Table 3. For protein and $\beta$-glucan, all the factors and most of the interactions were significant, the largest effects being due to year and genotype. On the other hand, genotype was the only significant factor for TDF. As a general trend, there was a significant variation in protein (from 15.39 to $15.99 \% \mathrm{~d}$.m.) and $\beta$-glucan (from 3.75 to $4.05 \% \mathrm{~d}$.m.) contents between the two extreme nitrogen levels (N0 and N80). In addition at all nitrogen levels, the seed rate of 400 seeds $\mathrm{m}^{-2}$ uniformly determined a slightly increase in protein and $\beta$-glucan content (data not shown).

In the second experiment the contents of protein, total and soluble $\beta$-glucan were explored in ten naked and two husked cultivars; Irina was the only genotype already present in the first experiment. From ANOVA, year resulted to be significant at $p \leq 0.05$ only for protein, whereas genotype and its interaction with year were significant at $p \leq 0.01$ for all the examined traits (data not shown).

\section{Environment effect on grain nutritional quality traits}

Box plots were used to summarize graphically the variability of measured parameters into and among years/environments (Fig. 2). The four growing seasons considerably differed for protein content (A), with 2007-08 (IV) showing the highest mean value (19.42\% d.m.) 
and 2005-06 the lowest (II, 15.05\% d.m.). Figure 2B illustrates the variation observed in the four years for total $\beta$-glucan content.

A larger variability was observed for this trait as compared to protein content where, in general, more compressed box plots were obtained; the highest mean value was observed in 2004-05 and in 2007-08 (I and IV, 4.16\% d.m.), whereas the lowest content (3.65\% d.m.) was measured in 2005-06 (II).

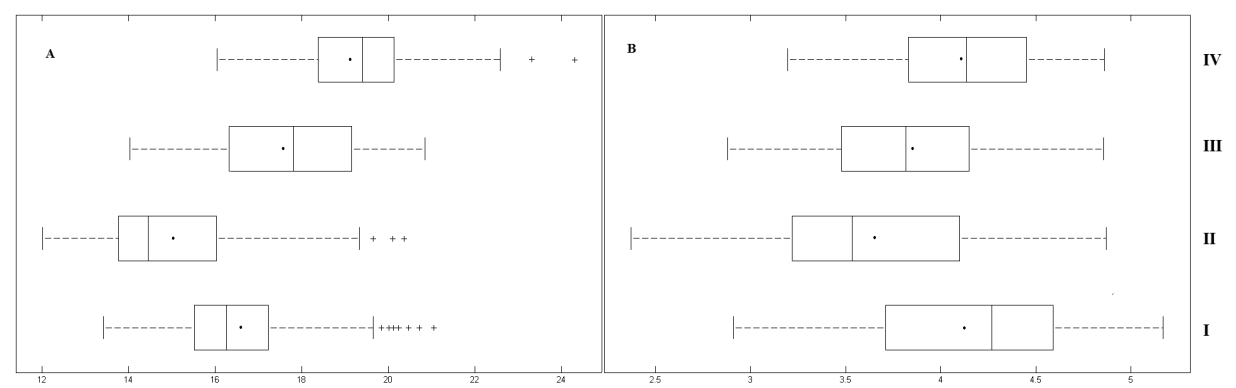

Figure 2. Box plots of protein (A) and total $\beta$-glucan (B) showing the variations in each year of the two experiments (from I, 2004-05 to IV, 2007-08). The line running through the middle of the box represents the median value, whereas the dot is the mean value; the box begins at the $25^{\text {th }}$ percentile and ends at $75^{\text {th }}$ percentile of data set

\section{Genotype effect on grain nutritional quality traits}

\section{First experiment}

Table 4 summarizes the values of the three compounds in the cultivars, averaged over years, nitrogen levels and seed doses. The highest contents of protein and $\beta$-glucan were

Table 4. Mean values (\% d.m.) of protein, total $\beta$-glucan and TDF in the genotypes from the first experiment (2004-06)

\begin{tabular}{lccc}
\hline Genotype & Protein $^{\text {a }}$ & Total $\beta$-glucan & TDF \\
\hline Naked cultivars & & & $12.43 \mathrm{c}$ \\
\hline Abel & $15.23 \mathrm{c}$ & $4.11 \mathrm{c}$ & $13.75 \mathrm{~b}$ \\
Hja72095N & $15.44 \mathrm{c}$ & $4.00 \mathrm{~d}$ & $12.33 \mathrm{c}$ \\
Irina & $15.51 \mathrm{c}$ & $3.98 \mathrm{~d}$ & $17.14 \mathrm{a}$ \\
Konradin & $13.81 \mathrm{e}$ & $3.15 \mathrm{f}$ & $10.84 \mathrm{~d}$ \\
Kynon & $14.81 \mathrm{~d}$ & $3.47 \mathrm{e}$ & $13.64 \mathrm{~b}$ \\
Rhea $\times$ Padarn & $15.31 \mathrm{c}$ & $3.43 \mathrm{e}$ & $11.23 \mathrm{de}$ \\
\hline Husked cultivars & & & $11.35 \mathrm{~d}$ \\
\hline Donata & $16.88 \mathrm{~b}$ & $4.45 \mathrm{~b}$ & 12.84 \\
Flavia & $19.29 \mathrm{a}$ & $4.65 \mathrm{a}$ & 0.59 \\
\hline Mean & 15.79 & 3.90 & 0.09 \\
LSD $p \leq 0.01$ & 0.37 & &
\end{tabular}

${ }^{a}$ Values in the same column with different letters are significantly different $(p \leq 0.01)$. 
found in the groats from husked cultivars Donata (16.88 and $4.45 \%$ d.m., respectively) and Flavia (19.29 and 4.65\% d.m.). TDF content was highest in cultivar Konradin $(17.14 \%$ d.m.) and lowest in Kynon (10.84\% d.m.), both of them naked cultivars. Simple correlation coefficients $(n=64)$ indicated a positive, significant correlation between protein and $\beta$-glucan $(r=0.76, p=0.01)$, whereas the correlation coefficient between TDF and $\beta$-glucan was negative $(r=-0.30, p=0.05)$; protein and TDF were not significantly correlated.

\section{Second experiment}

The mean values of the traits analyzed are reported in Table 5. Naked cultivars Luna and Hendon had the highest protein content (20.46 and 19.98\% d.m., respectively). Also, in this experiment the groats from husked cultivars were the richest in total $\beta$-glucan (4.48 and $4.39 \%$ d.m. for Bionda and Hamel), together with the naked cultivar Expression, which also had the highest soluble $\beta$-glucan content (4.40 and 3.70\% d.m., respectively). High percentages of water-soluble $\beta$-glucan were found in naked oats, ranging from 82.9 (Nave) to $90.7 \%$ (Hendon) (data not shown).

A sub-set of six cultivars released in Italy or United Kingdom in the period from 1983 (Nave) to 2009 (Irina and Luna), was also characterized for TDF and arabinoxylan (AX) content. Statistical analysis indicated that for AX the differences due to the year were not significant, whereas genotype and the interaction year $\times$ genotype were significant at $p \leq$ 0.01 . On the other hand, in this experiment TDF could not differentiate the cultivars, being more affected by the growing season ( $p \leq 0.05$, data not shown). Italian cultivar Irina was

Table 5. Mean values (\% d.m.) of protein, total and soluble $\beta$-glucan, TDF and AX in the genotypes from the second experiment

\begin{tabular}{|c|c|c|c|c|c|}
\hline Genotype & Protein $^{a}$ & $\begin{array}{c}\text { Total } \\
\beta \text {-glucan }\end{array}$ & $\begin{array}{c}\text { Soluble } \\
\beta \text {-glucan }\end{array}$ & TDF & $\mathrm{AX}$ \\
\hline \multicolumn{6}{|c|}{ Naked cultivars } \\
\hline BD123 & $19.24 \mathrm{ab}$ & $3.53 \mathrm{e}$ & $3.15 \mathrm{~cd}$ & & \\
\hline BD124 & $17.22 \mathrm{~cd}$ & $3.70 \mathrm{cde}$ & $3.29 \mathrm{bcd}$ & & \\
\hline Expression & $16.86 \mathrm{~d}$ & $4.40 \mathrm{a}$ & $3.70 \mathrm{a}$ & 13.67 & $1.59 \mathrm{ab}$ \\
\hline Grafton & $18.23 \mathrm{bcd}$ & $4.02 \mathrm{~b}$ & $3.58 \mathrm{ab}$ & 12.03 & $1.66 \mathrm{ab}$ \\
\hline Hendon & $19.98 \mathrm{a}$ & $3.78 \mathrm{~cd}$ & $3.43 \mathrm{abc}$ & & \\
\hline Irina & $17.54 \mathrm{~cd}$ & $3.93 \mathrm{bc}$ & $3.29 \mathrm{bcd}$ & 12.86 & $1.85 \mathrm{a}$ \\
\hline Luna & $20.46 \mathrm{a}$ & $3.73 \mathrm{cde}$ & $3.29 \mathrm{bcd}$ & 11.92 & $1.35 \mathrm{~b}$ \\
\hline Nave & $17.85 \mathrm{bcd}$ & $4.16 \mathrm{~b}$ & $3.45 \mathrm{abc}$ & 14.09 & $1.75 \mathrm{ab}$ \\
\hline Racoon & $18.29 \mathrm{bcd}$ & $3.58 \mathrm{de}$ & $3.09 \mathrm{~d}$ & & \\
\hline Zuton & $19.25 \mathrm{ab}$ & $4.07 \mathrm{~b}$ & $3.41 \mathrm{abcd}$ & 12.26 & $1.63 \mathrm{ab}$ \\
\hline \multicolumn{6}{|c|}{ Husked cultivars } \\
\hline Bionda & $18.48 \mathrm{bc}$ & $4.48 \mathrm{a}$ & $3.52 \mathrm{ab}$ & & \\
\hline Hamel & $18.58 \mathrm{bc}$ & $4.39 \mathrm{a}$ & $3.42 \mathrm{abcd}$ & & \\
\hline Mean & 18.50 & 3.98 & 3.39 & 12.80 & 1.64 \\
\hline $\operatorname{LSD} p \leq 0.01$ & 1.29 & 0.23 & 0.29 & ns & 0.44 \\
\hline
\end{tabular}

${ }^{\text {a }}$ Values in the same column with different letters are significantly different $(p \leq 0.01)$; ns = not significant 
the richest in $\mathrm{AX}(1.85 \%$ d.m.). Finally, in this set of genotypes no significant correlation among the traits considered was observed (data not shown).

\section{Discussion}

The effects of climatic factors on the nutritional composition of the oat grain was described by several authors, who tried to correlate specific weather conditions, in particular temperatures and water availability during the growth season, to the accumulation of $\beta$-glucan (Tiwari and Cummins 2009b). The results were contrasting: $\beta$-glucan was found to be affected by a reduced availability of water (Peterson 1991; Brunner and Freed 1994), or positively correlated to the amount of precipitation in July and August, and to warmer temperatures (Doehlert et al. 2001). Previous data also showed that both oat genotype and agronomic practises, as seeding season and rotation, can be important determinants of the variability of protein and $\beta$-glucan (Redaelli et al. 2009). In this context, our data confirm the observations by Havrlentová et al. (2013), who reported that yield is less sensitive to nitrogen fertilization in husked than in naked oats, whereas increasing nitrogen doses have a positive effect on $\beta$-glucan content, especially in husked genotypes. In the present study, where different oat genotypes and agronomical factors were tested in two consecutive experiments, the statistical evaluation of the differences in grain nutritional quality was synthesized graphically by box-plots, in which the four years were clearly differentiated, and a larger variability for $\beta$-glucan content as compared to proteins was observed. Protein content resulted to be inversely correlated to yield, which was higher in the first experiment than in the second. On the other hand, $\beta$-glucan resulted to be highest in the first and the fourth year of the trials (2004-05 and 2007-08), although the two seasons were quite different in terms of rainfall during spring time. Rainfall was in fact mainly distributed in winter 2004, whereas in 2007-08 rainfall was quite abundant in the period corresponding to plant heading and grain maturation. A similar result was observed in the comparison of a group of European oat genotypes, grown in five environments with contrasting characteristics of mean temperatures and rainfall (Redaelli et al. 2013). Interestingly, a positive correlation between protein and $\beta$-glucan contents was found in the first experiment and a similar trend was observed in the second experiment; these results could be advantageous to breeders in order to improve oat genotypes in terms of grain quality traits. However, other studies (Brunner and Freed 1994; Peterson et al. 2005; Redaelli et al. 2009) pointed out that environmental factors could affect the correlations between grain chemical traits. Additional research could be useful to clarify the interactions between agronomical and environmental traits and oat genotypes.

In the first experiment TDF was shown to be strongly determined by the genotype, in fact a large variability was observed among the varieties; this trait was also found to be unaffected both by fertilization level and seed dose. On the other hand, the differences of TDF content in six naked cultivars from the second experiment were not significant. AX normally constitutes $14 \%$ of endosperm cell walls in oats and $\mathrm{AX}$ and $\beta$-glucan are the main components of TDF of oat whole grains, where AX could vary between $2-4.5 \%$ 
(MacArthur-Grant 1986). In the examined naked oats, AX showed lower values, ranging from 1.35 to $1.85 \%$ d.m.

The genetic origin of the cultivars analyzed was found to have the largest effect on $\beta$-glucan accumulation and the comparison of Irina performances evidenced significant differences between the two experiments only in protein contents. In addition, the best nutritional quality was observed in the groats from the four husked cultivars. As for naked cultivars, for example, Luna and Irina (released in 2009) were richest in protein and arabinoxylan content, respectively, but not so rich in terms of $\beta$-glucan fractions; also Zuton (released in 2006) was not distinguished from the others for its composition. Similar results were also observed by Givens et al. (2000) which evidenced less $\beta$-glucan in naked oat in comparison with de-hulled oat grain. In recent years, genetic breeding for naked oats has contributed considerably to the development of cultivars with a higher yield potential, as the gap of production between husked and naked genotypes was a major hindrance to their diffusion. However, these results highlight the need to improve naked oats also in terms of grain nutritional quality since they represent, from the technological point of view, a convenient raw material for the food industry.

\section{References}

Åman, P., Graham, H. 1987. Analysis of total and insoluble mixed-linked (1-3), (1-4) $\beta$-glucans in barley and oats. J. Agricultural \& Food Chem. 35:704-709.

AOAC Method 991.42, Insoluble Dietary Fiber in Food and Food Products - Enzymatic-Gravimetric Method, Phosphate Buffer. Official Methods of Analysis, $16^{\text {th }}$ ed. AOAC International, Gaithersburg, MD, 1995.

Arentz-Hansen, H., Fleckenstein, B., Molberg, O., Scott, H., Koning, F. et al. 2004. The molecular basis for oat intolerance in celiac disease patients. PloS Med. 1:e1.

Brennan, C.S., Cleary, L.J. 2005. The potential use of cereal $(1 \rightarrow 3,1 \rightarrow 4)-\beta$-D-glucan as functional food ingredients. J. Cereal Sci. 42:1-13.

Brunner, B.R., Freed, R.D. 1994. Oat grain $\beta$-glucan content as affected by nitrogen level, location and year. Crop Sci. 34:473-476.

Ciccoritti, R., Scalfati, G., Cammerata, A., Sgrulletta, D. 2011. Variations in content and extractability of durum wheat (Triticum turgidum L. var. durum) arabinoxylans associated with genetic and environmental factors. Int. J. Mol. Sci. 12:4536-4549.

Davy, B.M., Davy, K.P., Ho, R.C., Beske, S.D., Davrath, L.R., Melby, C.L. 2002. High-fiber oat cereal compared with wheat cereal consumption favourably alters LDL-cholesterol subclass and particle numbers in middled-aged and older men. Am. J. Clinical Nutrition 76:351-358.

Doehlert, D.C., McMullen, M.S., Hammond, J.J. 2001. Genotypic and environmental effects on grain yield and quality of oat grown in North Dakota. Crop Sci. 41:1066-1072.

Englyst, H.N., Quigley, M.E., Hudson, G.J. 1994. Determination of dietary fibre as non-starch polysaccharides with gas-liquid chromatographic, high-performance liquid chromatographic or spectrophotometric measurement of constituent sugars. Analyst 119:1497-1509.

Givens, D.I., Davies, T.W., Laverick, R.M. 2000. Dietary fibre fractions in hulled and naked winter oat grain: effects of cultivars and various agronomic factors. J. Sci. of Food \& Agriculture 80:491-496.

Haboubi, N.Y., Taylor, S., Jones, S. 2006. Coeliac disease and oats: A systematic review. Postgrad. Med. J. 82:672-678.

Havrlentová, M., Hlinková, A., Žofajová, A., Kováčic, P., Dvončová, D., Deáková, L. 2013. Effect of fertilization on $\beta$-D-glucan content in oat grain (Avena sativa L.). Agriculture 59:111-119.

Jenkins, D.J., Kendall, C.W., Vuksan, V., Parker, T., Faulkner, D., Mehling, C.C., Garsetti, M., Testolin, G., Cunnane, S.C., Ryan, M.A., Corey, P.N. 2002. Soluble fiber intake at a dose approved by the US Food and 
Drug Administration for a claim of health benefits: serum lipid risk factors for cardiovascular disease assessed in a randomized controlled crossover trial. Am. J. Clinical Nutrition 75:834-839.

Lee, C.J., Horsley, R.D., Manthey, F.A., Schwarz, P.B. 1997. Comparisons of $\beta$-glucan content of barley and oat. Cereal Chem. 74:571-575.

Lim, H.S., White, P.J., Frey, K.J. 1992. Genotypic effects on $\beta$-glucan content of oat lines grown in two consecutive years. Cereal Chem. 69:262-265.

Liu, R.H. 2007. Whole grain phytochemicals and health. J. Cereal Sci. 46:207-219.

MacArthur-Grant, L.A. 1986. Sugars and non-starchy polysaccharides in oats. In: Oats: Chemistry and Technology, Webster, F.H. (Ed.), Saint Paul, MN, USA, pp. 75-91.

McCleary, B.V., Codd, R. 1991. Measurement of (1-3) (1-4) $\beta$-glucan in barley and oats enzymic procedure. J. Sci. of Food \& Agriculture 53:303-310.

Peltonen-Sainio, P., Kirkkari, A.-M., Jauliainen, L. 2004. Characterising strengths, weaknesses, opportunities and threats in producing naked oat as a novel crop for northern growing conditions. Agricultural \& Food Sci. 13:212-228.

Peterson, D.M. 1991. Genotype and environment effects on oat $\beta$-glucan concentration. Crop Sci. 31:1517-1520.

Peterson, D.M. 1992. Composition and nutritional characteristics of oat grain and products. In: Oat Science and Technology. Marshall, H.G. and Sorrells, M.E. (Eds), Madison, WI, USA, pp. 265-292.

Peterson, D.M., Wesenberg, D.M., Burrup, D.E., Erickson, C.A. 2005. Relationship among agronomic traits and grain composition in oat genotypes grown in different environments. Crop Sci. 45:1249-1255.

Redaelli, R., Sgrulletta, D., Scalfati, G., De Stefanis, E. 2006. Development of naked-oat products with suitable nutritional properties for improving health. Tecnica Molitoria International 57(5/A):109-115.

Redaelli, R., Sgrulletta, D., Scalfati, G., De Stefanis, E. 2007. New naked oat genotypes for producing functional foods. J. Genet. \& Breed. 61:63-68.

Redaelli, R., Sgrulletta, D., Scalfati, G., De Stefanis, E., Cacciatori, P. 2009. Naked oats for improving human nutrition: Genetic and agronomic variability of grain bioactive components. Crop Sci. 49:1431-1437.

Redaelli, R., Del Frate, V., Bellato, S., Terracciano, G., Ciccoritti, R., Germeier, C.U., De Stefanis, E., Sgrulletta, D. 2013. Genetic and environmental variability of total and soluble $\beta$-glucan in European oat genotypes. J. Cereal Sci. 57:193-199.

Saastamoinen, M., Hietaniemi, V., Pihlava, J-M., Eurola, M., Kontturi, M., Tuuri, H., Nisanen, M., Kangas, A. 2004. $\beta$-Glucan contents of groats of different oat cultivars in official variety, in organic cultivation, and in nitrogen fertilization trials in Finland. Agric. Food Sci. 13:68-79.

Sgrulletta, D., Redaelli, R., Scalfati, G., De Stefanis, E., Pollini, C.M. 2008. New opportunities from naked oat breeding for Italian pasta industry market. Tecnica Molitoria International 59(9/A):139-148.

Sgrulletta, D., Scalfati, G., De Stefanis, E., Redaelli, R., Pollini, C.M. 2005. Naked oat-based pasta. Quality variability in relation to cultivar characteristics. Tecnica Molitoria International 56(4/A): 116-125.

Shewry, P.R., Piironen, V., Lampi, A-M., Nyström, L., Li, L., Rakszegi, M., Fraœ, A., Boros, D., Gebruers, K., Courtin, C.M., Delcour, J.A., Andersson, A.A.M., Dimberg, L., Bedő, Z., Ward, J.L. 2008. Phytochemical and fiber components in oat varieties in the healthgrain diversity screen. J. Agriculture \& Food Sci. 56:9777-9784.

Slavin, J.L., Martini, M.C., Jacobs, D.R., Marquart, L. 1999. Plausible mechanisms for the protectiveness of whole grains. Am. J. Clinical Nutrition 70 (Suppl.):459S-463S.

Tiwari, U., Cummins, E. 2009a. Factors influencing $\beta$-glucan levels and molecular weight in cereal-based products. Cereal Chem. 86:290-301.

Tiwari, U., Cummins, E. 2009b. Simulation of the factors affecting $\beta$-glucan levels during the cultivation of oats. J. Cereal Sci. 50:175-183.

Weightman, R.M., Heywood, C., Wade, A., South, J.B. 2004. Relationship between grain (1-3,1-4)- $\beta$-D-glucan concentration and the response of winter-sown oats to contrasting forms of applied nitrogen. J. Cereal Sci. 40:81-86. 